\title{
Strategi Pengentasan Kemiskinan di Pulau Kecil di Propinsi Maluku
}

\author{
Wardis Girsang \\ Fakultas Pertanian Universitas Pattimura \\ Kampus Poka-Ambon 97233 \\ Korespondensi: girsang_2010@yahoo.com
}

\begin{abstract}
Poverty alleviation strategy in small islands in Maluku province

Poverty is still a crucial problem in Indonesia, although the number tends to decrease from 39 million in 2006 to 33 million (14.5\%) in 2008. Most of them were farmers particularly food crop farmers. In Maluku, the number of poor people was almost twofold higher than national level that was $29 \%$. Primary data was collected from farmer's household by using survey and focus group discussion. Research showed that actively poor farmers spread in small islands, live in subsistence farm, low income and unable to fulfill basic need. It was recommended that the main priority strategy to reduce poverty were improving household income through developing prime commodity agribusiness in each small island, subsidies of production inputs for farmer, facilitating access to market as well as village productive groups revitalization.
\end{abstract}

Keywords: Agribusiness, Poverty, Prime commodity, Small islands.

\begin{abstract}
ABSTRAK
Kemiskinan masih menjadi salah satu persoalan serius di Indonesia walaupun angka kemiskinan cenderung menurun dari 39 juta pada tahun 2006 menjadi 33 juta atau $15.5 \%$ pada tahun 2008. Bagian terbesar dari penduduk miskin itu adalah petani, khususnya petani tanaman pangan. Di Maluku, angka kemiskinan hampir dua kali lipat dibanding angka kemiskinan nasional yakni sekitar $29 \%$. Data penelitian telah dikumpulkan dari sejumlah rumah tangga petani melalui survai dan kelompok diskusi fokus. Hasil penelitian menunjukkan bahwa petani miskin yang aktif secara ekonomi tersebar di pulau-pulau kecil. Mereka memiliki pola usahatani subsisten dan berpendapatan rendah serta kurang mampu memenuhi kebutuhan dasar. Kajian ini merekomendasikan untuk mengentaskan kemiskinan melalui pengembangan agribisnis komoditi unggulan di tiap pulau yang didukung subsidi input produksi, fasilitasi akses terhadap pasar serta revitalisasi atau penguatan kapasitas kelembagaan kelompok produktif di pedesaan.
\end{abstract}

Kata kunci: Agribisnis, Kemiskinan, Komoditas unggulan, Pulau kecil.

\section{PENDAHULUAN}

Kemiskinan mempunyai sifat multidimensi sehingga didefinisikan berbeda oleh orang yang memiliki perspektif berbeda, namun demikian umumnya kemiskinan diukur dari penyebab kemiskinan yakni tingkat pendapatan. Bank Dunia menggunakan standar pengeluaran 2 dollar AS per hari sedangkan BPS menggunakan ukuran kebutuhan dasar 2100 kalori atau setara Rp 152.487 per kapita per bulan. Standar garis kemiskinan demikian cukup sensitif terhadap perubahan ukuran sehingga berdampak besar pada jumlah penduduk miskin. Ukuran lain yang sering digunakan adalah live poverty index meliputi tingkat konsumsi kalori, kondisi rumah, pendidikan, kondisi kesehatan, konsumsi minyak goreng, akses ke air bersih, dan daya beli.

Terlepas dari perdebatan ukuran yang digunakan, kemiskinan masih merupakan salah satu persoalan fundamental di Indonesia. Selama 30 tahun lebih pemerintahan Orde Baru (1969-1999), 
disusul oleh pemerintahan di era reformasi, kabinet gotong royong dan Kabinet Indonesia Bersatu, angka kemiskinan masih tergolong tinggi. Jika tahun 2004, angka kemiskinan mencapai 36 juta orang, tahun 2006 meningkat menjadi 39,1 juta orang (17,75\%) dan diperkirakan sekitar 32 juta tahun 2008 (BPS, 2009). Berbeda dengan BPS, Bank Dunia (2006) mengestimasi jumlah penduduk miskin di Indonesia mencapai 109 juta (49 \%) karena kenaikan harga beras dan adanya krisis pangan, energi dan keuangan.

Jumlah penduduk miskin terbesar (55\%) di Indonesia adalah petani di pedesaan dan $75 \%$ diantaranya adalah rumah tangga petani tanaman pangan dan palawija (Arifin, 2007). Kemiskinan petani diduga berkaitan erat dengan makin meluasnya konversi lahan pertanian, sempitnya pemilikan dan pengusahaan luas lahan usahatani serta terbatasnya peluang bekerja dan berusaha. Data Sensus Pertanian di Jawa menunjukkan bahwa jumlah petani gurem cenderung meningkat dari 10,8 juta (52,7 \%) tahun 1993 menjadi 13,7 juta (56,5 \%) pada tahun 2003.

Berbeda dengan angka rata-rata kemiskinan di Indonesia, angka kemiskinan di Maluku yang 96.5 \% wilayahnya terdiri dari lautan adalah 29, 7 \% (BPS Maluku, 2008) atau dua kali lebih tinggi dibanding angka kemiskinan nasional (14.5\%). Jika dibanding antar kabupaten, angka kemiskinan bahkan jauh lebih tinggi karena bervariasi antara $18 \%$ di kota Ambon dan rata-rata sekitar $52 \%$ di kabupatenkabupaten lain yang terdiri dari pulau-pulau kecil. Pulau kecil menurut UNESCO yang melihat dari perspektif Hidrologi, yakni pulau yang mempunyai luas kurang dari $1000 \mathrm{~km}^{2}$ (Kakazu, 1994, dalam Stubenvoll, 2001), sedangkan menurut kategori 'land area', pulau kecil tropis merupakan konsep relatif bukan absolute, yakni suatu pulau yang luasnya kurang dari $10.000 \mathrm{~km}^{2}$ dengan penduduk sekitar 500.000 jiwa dimana variasi temperatur harian lebih tinggi dari musiman. Berdasarkan definisi demikian, hampir semua pulau di Maluku tergolong sebagai pulau-pulau kecil.

Berbeda dengan di Jawa, pulau-pulau kecil mempunyai karakteristik khusus antara lain rentang kendali (span of control) laut yang sulit antar pulau, rawan bencana alam, erosi, dan sulit aksessibilitas air bersih serta secara kultural sensitif konflik oleh karena benturan kepentingan atas nama pembangunan dan aspirasi masyarakat lokal, khususnya eksploitasi hutan dan pertambangan. Keterbatasan sarana dan prasarana dasar sosial ekonomi, transportasi dan komunikasi antar pulau, akan menciptakan akses pasar terbatas, sulitnya mengembangkan skala ekonomi usahatani dan isolasi (Chambers, 1983).

Pertumbuhan ekonomi Maluku mencapai 6,17\% tahun 2008 dengan nilai ekspor Maluku yang diperkirakan rata-rata $\mathrm{Rp}$ 828,5 miliar per tahun (BKPMD Promal, 2007) baik berupa hasil laut, perkebunan dan kehutanan. Namun kualitas pertumbuhan ekonomi Maluku masih dipertanyakan mengingat kesenjangan yang cukup tinggi antara ibu kota provinsi kota Ambon dengan ibu kota kabupaten lain dan tingginya angka pengangguran (14\%) dan kemiskinan (29\%). Kecuali itu, investasi dan nilai ekspor ternyata tidak mempengaruhi pemerataan. Lebih jauh, pendapatan per kapita masih rendah yakni sekitar Rp 3,26 juta/kapita/ tahun, lebih rendah dibanding tingkat pendapatan rata-rata per kapita nasional dan provinsi lain seperti Gorontalo dan Sulawesi Tenggara. Jadi pertumbuhan ekonomi yang didorong investasi dan ekspor terjadi tanpa diikuti pemerataan.

Penelitian masalah kemiskinan di pulaupulau kecil Propinsi Maluku masih terbatas. Oleh karena itu penelitian ini penting dilakukan sebagai salah satu upaya memperoleh manfaat bagi pengembangan strategi dan kebijakan pengentasan kemiskinan di pulau-pulau kecil. Secara spesifik tujuan tulisan ini ada tiga: 1) mempelajari karakteristik rumah tangga miskin, khususnya di kawasan pulau-pulau kecil; 2) mencari faktor-faktor penyebab kemiskinan; dan 3) mengembangkan strategi penanggulangan kemiskinan di pulau-pulau kecil

\section{BAHAN DAN METODE}

\section{Penentuan Lokasi Penelitian}

Lokasi kajian dipilih berdasarkan jarak yang cukup jauh dari ibukota propinsi (Ambon), yakni Kabupaten Maluku Tenggara Barat (MTB) karena memiliki angka kemiskinan yang cukup tinggi (51 \%). Berdasarkan pertimbangan aksessibilitas wilayah penelitian yang sangat sulit, musim ombak dan jauhnya jarak dari pusat ibukota kabupaten, maka lokasi penelitian di tingkat kabupaten ditentukan di bagian Selatan Kabupaten MTB yang meliputi 8 desa di empat kecamatan yakni yakni Desa Amdasa dan Aruibab di Kecamatan Wertamrian, Desa Adaut dan Kandar di Kecamatan Selaru, Desa Lermatang dan Latdalam di Kecamatan Tanimbar Selatan, serta Desa Makatian dan Desa Marantutul di Kecamatan 
Wermaktian. Penelitian ini dilakukan antara tahun 2007 dan 2008.

\section{Penentuan Responden}

Responden di tiap desa penelitian ditentukan secara sengaja sebanyak 10 rumah tangga petani sehingga jumlah responden penelitian adalah 60 rumah tangga petani. Rumah tangga petani yang menjadi responden dipilih berdasarkan luas lahan usahatani yang diusahakan. Kepala desa beserta kepala urusan umum dan urusan pembangunan, tokoh pendidikan serta tokoh adat turut dijadikan informan kunci dalam penelitian di tiap desa. Selain itu, informan di tingkat kabupaten mewakili institusi dewan perwakilan rakyat, pemerintah daerah Kabupaten MTB, khususnya Kepala Dinas Pertanian dan staf, Kepala Dinas Pendidikan dan Kebudayaan, Kepala Dinas Kehutanan dan Perkebunan, Kepala Dinas Perindustrian dan Perdagangan, Kepala Dinas Perikanan dan Kelautan, Kepala Badan Statistik serta Pimpinan dan Staf Sekolah Kejuruan Pertanian dan Kelautan.

\section{Pengumpulan data}

Data mengenai konsep kemiskinan dan produksi usahatani dikumpulkan melalui wawancara mendalam (in-depth interview) dengan rumah tangga petani di tiap desa. Jumlah populasi 8 desa penelitian adalah 1.639 kepala keluarga petani dan jumlah sampel yang dipilih secara sengaja adalah sekitar 164 kepala keluarga. Mereka yang dipilih secara sengaja ada meliputi petani, aparat desa, ibu rumah tangga dan tokoh masyarakat. Selanjutnya, rumah tangga yang menjadi responden di tiap desa tersebut difasilitasi untuk berkumpul dan berdiskusi bersama dengan metode diskusi kelompok fokus untuk menggali data pengeluaran rumah tangga. Data yang telah dikumpulkan dari rumah tangga petani kemudian dilengkapi dengan melakukan diskusi antara petani bersama aparat pemerintahan desa dan staf serta tokoh masyarakat untuk menggambarkan keterkaitan sebab akibat kemiskinan. Pada tingkat kabupaten, data yang telah dikumpulkan dari desa kemudian diolah dan dipresentasikan di tingkat kabupaten untuk verifikasi dan memperoleh masukan dari pemerintah daerah, khususnya dinas pertanian dan dinas terkait lainnya. Di samping data primer, terdapat data sekunder mengenai kemiskinan yang dikumpulkan dari Badan Pusat Statistik dan dokumen laporan pemerintah daerah Kabupaten MTB serta sumber kepustakaan yang relevan.

\section{Analisis Data}

Data penelitian yang telah dikumpulkan dari rumah tangga petani kemudian diperiksa dan didiskusikan kembali sebelum diolah dengan Microsoft Office Excel 2007. Data produksi usahatani dan pendapatan rumah tangga diolah dan dilakukan analisis pengeluaran rumah tangga. Data pengeluaran kemudian dikategorikan berdasarkan pengeluaran untuk kebutuhan pangan dan non-pangan selama setahun untuk dianalisis secara kualitatif dan ditampilkan dalam bentuk tabulasi persentase. Data hasil catatan lapangan dan hasil diskusi kelompok fokus maupun catatan hasil seminar di tingkat kabupaten kemudian dikategorikan sesuai isi yang dibahas (content analysis) dan relevan untuk memperkaya jawaban terhadap pertanyaan penelitian.

\section{HASIL DAN PEMBAHASAN}

\section{Karakteristik Kemiskinan Tingkat Kecamatan}

Kabupaten Maluku Tenggara Barat (MTB) merupakan salah satu dari 11 kabupaten/kota di Propinsi Maluku. Secara umum, pertanian memberi kontribusi terbesar (52 \%) terhadap persentase PDRB di Kabupaten MTB. Potensi sumberdaya pertanian cukup melimpah dengan lahan kering seluas 415.769 ha dan kehutanan diperkirakan seluas 96.5847 ha. Di samping itu terdapat sumber daya manusia nelayan sekitar 7.613 rumah tangga yang tinggal di wilayah pesisir pantai. Pemanfaatan potensi sumberdaya ikan diperkirakan sekitar $30 \%$, masih jauh dibawah potensi lestari (MSY) yakni 25.345,11 ton tahun $^{-1}$ dan jumlah tangkapan yang diperbolehkan (JTB) yakni 20.276,09 ton tahun $^{-1}$. Pertumbuhan ekonomi kabupaten MTB cenderung meningkat dari 3,32 \% tahun 2004 menjadi 5,11\% tahun 2007 dengan tingkat pendapatan per kapita sekitar 3,45 juta/tahun.

Masalahnya, menurut laporan Bappeda MTB (2007) tingkat kemiskinan di kabupaten MTB mencapai 50,5 \% dari total penduduk sekitar 93265 jiwa. Angka kemiskinan di kabupaten MTB sekitar 1,8 kali lebih tinggi dari angka kemiskinan Maluku atau 3,5 kali lebih tinggi dari rata-rata angka kemiskinan nasional. Penduduk miskin tersebut tersebar di pulau-pulau seperti Selaru, Tanimbar dan Tanimbar Utara di 9 wilayah kecamatan. Karakteristik petani dan nelayan miskin adalah menggunakan teknologi konvensional. Umumnya pertanian dilakukan tanpa input dan $81 \%$ nelayan 
memiliki perahu tanpa motor dan $87 \%$ masih tergantung dari teknologi jaring insang dan pancing.

Jumlah rumah tangga miskin dan sangat miskin adalah 11.318 rumah tangga atau 50.931 jiwa (asumsi 4,5 jiwa per keluarga). Dengan demikian angka kemiskinan di Kabupaten MTB adalah sekitar $54.61 \%$ yang tersebar di sembilan Kecamatan. Persentase kemiskinan tertinggi ditemukan di Kecamatan Selaru dan Tanimbar Utara sedangkan yang terendah di kecamatan Yaru (Tabel 1).

Limpahan tenaga kerja di sektor pertanian dan pedesaan masuk ke sektor informal. Data menunjukkan bahwa sekitar $83 \%$ tenaga kerja bekerja di sektor informal, $13 \%$ di sektor formal dan $4 \%$ tidak bekerja. Imbas kemiskinan adalah urbanisasi berlebih yang menciptakan kemiskinan dan sektor informal di pusat kota (Harris dan White, 2005), khususnya Kota Ambon yang telah mencapai kepadatan penduduk sekitar 700 jiwa $/ \mathrm{km}^{-2}$ atau 28 kali lebih padat dibanding kepadatan kabupaten yang rata-rata 25 jiwa $/ \mathrm{km}^{-2}$. Menurut Tambunan (1995) oleh karena biaya hidup yang tinggi di perkotaan maka pendapatan di sektor informal tidak jauh berbeda dari pendapatan pertanian di pedesaan. pedesaan setara beras $320 \mathrm{~kg}$ kapita $^{-1}$ tahun $^{-1}$ atau $1600 \mathrm{~kg}$ rumah tangga ${ }^{-1} /$ tahun $^{-1}$, garis kemiskinan di pedesaan adalah sekitar Rp 533.000 per rumah tangga per bulan. Berdasarkan ukuran tersebut diperoleh hasil penelitian lapang di delapan desa (Fakultas Pertanian Unpatti, 2007) bahwa jumlah penduduk miskin di pedesaan MTB adalah 1) 51.85 $\%$ rumah tangga petani tergolong miskin, 2) $40.74 \%$ pas-pasan (hampir miskin) dan 3) $7.41 \%$ yang tidak miskin. Kelompok 'hampir miskin' tersebut merupakan rumah tangga yang sangat rentan menjadi miskin ketika terjadi gagal panen atau harga jual rendah.

Berdasarkan pada pendekatan pengeluaran rumah tangga per tahun, potret kemiskinan di pedesaan kabupaten MTB menunjukkan bahwa total pengeluaran rumah tangga petani di lima desa tidak jauh berbeda yakni berkisar antara Rp 5,12 juta dan Rp 6,67 juta atau rata-rata sekitar Rp 6,3 juta per tahun. Mengingat jumlah anggota rumah tangga berkisar antara 4-5 orang maka pendapatan per kapita per bulan berkisar antara Rp 104.354 dan Rp 130.442. Jika nilai pendapatan ini dijadikan sebagai ukuran tingkat kemiskinan maka petani di

Tabel 1. Persebaran penduduk miskin menurut kecamatan di kabupaten Maluku Tenggara Barat

\begin{tabular}{|c|c|c|c|c|c|c|c|c|}
\hline \multirow[b]{2}{*}{ No } & \multirow[b]{2}{*}{ Kecamatan } & \multirow{2}{*}{$\begin{array}{c}\text { Jumlah } \\
\text { Desa }\end{array}$} & \multirow{2}{*}{$\begin{array}{l}\text { Jumlah } \\
\text { Dusun }\end{array}$} & \multicolumn{3}{|c|}{ Jumlah rumah tangga } & \multicolumn{2}{|c|}{ Tingkat kemiskinan } \\
\hline & & & & $\begin{array}{l}\text { Hampir } \\
\text { miskin }\end{array}$ & Miskin & $\begin{array}{l}\text { Sangat } \\
\text { miskin }\end{array}$ & Jiwa & Persen*) \\
\hline 1 & Tanimbar Selatan & 9 & 3 & 310 & 970 & 216 & 5.337 & 5,72 \\
\hline 2 & Selaru & 6 & 1 & 365 & 1.604 & 346 & 8.775 & 9,41 \\
\hline 3 & Wertamrian & 8 & 1 & 236 & 986 & 254 & 5.580 & 5,98 \\
\hline 4 & Wermaktian & 8 & 1 & 199 & 927 & 355 & 5.769 & 6,19 \\
\hline 5 & Tanimbar Utara & 8 & 0 & 307 & 1.157 & 318 & 6.638 & 7,12 \\
\hline 6 & Yaru & 6 & 0 & 134 & 416 & 262 & 3.051 & 3,27 \\
\hline 7 & Nirunmas & 5 & 0 & 119 & 924 & 111 & 4.658 & 4,99 \\
\hline 8 & Kormomolin & 9 & 1 & 215 & 887 & 266 & 5.189 & 5,56 \\
\hline 9 & Wuarlabobar & 12 & 5 & 226 & 1.044 & 275 & 5.936 & 6,36 \\
\hline & Jumlah & 71 & 12 & 2.111 & 8.915 & 2.403 & 50.931 & 54,61 \\
\hline
\end{tabular}

Sumber: Dinas Kesejahteraan Sosial, Tenaga Kerja dan Transmigrasi Kabupaten MTB, 2008

*) Dari 93.265 jiwa penduduk, 50.931 jiwa (54,6 \%) miskin, 10,2 \% hampir miskin dan 35,2 \% tidak miskin.

\section{Karakteristik Kemiskinan Tingkat Rumah Tangga Petani}

Indikator kemiskinan petani dapat dilihat dari pendekatan pengeluaran rumah tangga. Mengadopsi garis kemiskinan menurut Sajogyo (1978) untuk pedesaan Kabupaten MTB masih hidup berada di bawah garis kemiskinan sebesar Rp 152.487/kapita per bulan jika dibanding rata-rata pendapatan per kapita Propinsi Maluku (kota dan desa) sekitar Rp 271.667 per kapita per bulan. Walaupun 
pendapatan dibawah garis kemiskinan, petani di Maluku umumnya jarang mengalami kasus kelaparan karena memperoleh karbohidrat dari pangan non beras yang cukup potensial di tiap pulau. Dengan demikian kemiskinan petani Maluku bukan miskin pangan (kalori) tetapi miskin pendapatan (uang tunai).

Tabel 2 menunjukkan bahwa rumah tangga petani mengalokasikan sekitar $71 \%$ pengeluarannya untuk pangan, termasuk rokok dan $29 \%$ untuk non pangan. Komponen pengeluaran pangan terbesar adalah beras, sedang pengeluaran non pangan terbesar adalah biaya pendidikan anak (11\%) baik sekolah dasar, sekolah lanjutan maupun perguruan tinggi, disusul oleh transportasi dan listrik. Dengan demikian kemiskinan yang didefinisikan sebagai pemuda terdidik karena rendahnya apresiasi terhadap pekerjaan sebagai petani. Penduduk usia muda lebih banyak memilih migrasi ke ibukota kabupaten dan provinsi untuk mencari pekerjaan, sehingga terjadi kelangkaan tenaga kerja petanian di pulau-pulau kecil.

Secara spesifik, petani miskin di pedesaan Maluku Tenggara Barat memiliki budaya tnyafar. Tnyafar merupakan tempat tinggal (rumah) kedua, sebagai upaya mengatasi kendala jarak yang cukup jauh dan transportasi yang terbatas antara kebun dan rumah di desa. Petani dan keluarganya, kecuali anak yang sekolah, akan berada di kebun antara 2 dan 5 hari, kemudian kembali ke rumah pada hari sabtu dan minggu untuk beribadah.

Tabel 2 Jenis dan tingkat pengeluaran rumah tangga per tahun menurut desa

\begin{tabular}{lrrrrrrr}
\hline \multirow{2}{*}{ Jenis pengeluaran } & \multicolumn{9}{c}{ Pengeluaran $(\mathrm{Rp})^{*}$} & \multicolumn{2}{c}{ Rata-rata } \\
\cline { 2 - 8 } & \multicolumn{1}{c}{ Amdasa } & \multicolumn{1}{c}{ Aruibab } & \multicolumn{1}{c}{ Adaut } & \multicolumn{1}{c}{ Kandar } & Lermatang & \multicolumn{1}{c}{ Rp } & \multicolumn{1}{c}{$\%$} \\
\hline Makanan & 4.272 .159 & 4.553 .375 & 4.461 .111 & 4.562 .500 & 2.208 .996 & 4.011 .628 & 64,07 \\
Rokok & 400.636 & 270.400 & 534.444 & 520.000 & 459.996 & 437.095 & 6,98 \\
Minyak (tanah) & 460.909 & 748.800 & 242.667 & 468.000 & 920.004 & 568.076 & 9,07 \\
Pendidikan & 936.000 & 558.000 & 687.333 & 240.000 & 961.500 & 676.567 & 10,81 \\
Transportasi & 225.909 & 177.300 & 125.000 & 200.000 & 300.000 & 205.642 & 3,28 \\
Listrik & 101.455 & 92.400 & 174.667 & 150.000 & 24.996 & 108.703 & 1,74 \\
Kesehatan & 106.818 & 104.500 & 72.500 & 100.000 & 100.000 & 96.764 & 1,55 \\
Perbaikan rumah & 90.000 & 89.250 & 100.000 & 100.000 & 89.000 & 93.650 & 1,50 \\
Kegiatan sosial & 62.273 & 80.500 & 67.778 & 50.000 & 55.000 & 63.110 & 1,01 \\
Total & 6.656 .159 & 6.674 .525 & 6.465 .500 & 6.390 .500 & 5.119 .492 & 6.261 .235 & 100 \\
\hline
\end{tabular}

*) Data pengeluaran untuk tiga desa lainnya (Marantutul, Makatian dan Latdalam) kurang lengkap sehingga tidak ditampilkan dalam Tabel 2, sedangkan data produksi petani di tiap desa ditampilkan pada Tabel 3.

ketidakmampuan memenuhi kebutuhan dasar juga berlaku di pulau-pulau kecil, khususnya non pangan. Biaya kesehatan tergolong kecil sebab pemeriksaan kesehatan yang disebabkan oleh penyakit ringan bukan prioritas bagi penduduk miskin.

Karakteristik lain petani miskin di pedesaan pulau-pulau kecil Maluku antara lain berpendidikan rendah, berusia tua, memiliki beban tanggungan antara 4 dan 6 jiwa, usahatani subsisten, tenaga kerja produktif terbatas, teknologi konvensional, ladang berpindah dan akses terbatas terhadap inovasi baru dan penyuluh agribisnis. Hal ini dapat berarti pertanian memang tidak menarik minat para

\section{Faktor penyebab kemiskinan}

Berdasarkan hasil observasi dan kajian lapang, definisi kemiskinan sebagai ketidakmampuan memenuhi kebutuhan dasar pangan dan non pangan (Tjondronegoro et al., 1996) merupakan definisi yang menekankan akibat (bukan sebab) kemiskinan. Kondisi rumah dan tingkat pendapatan akibat kemiskinan. Oleh sebab itu, hubungan sebab akibat kemiskinan dan strategi penanggulangannya perlu dicari. Sebab akibat kemiskinan saling terkait satu sama lain dan penyebab kemiskinan selalu bersifat multidimensi baik penyebab internal maupun struktural atau eksternal (Alcock, 1997). 
Kemiskinan yang terjadi adalah kemiskinan pendapatan yang berkaitan langsung dengan dua sisi yakni tabungan dan investasi rendah serta harga jual produk yang rendah. Investasi rendah mengakibatkan petani tidak mampu mengadopsi inovasi sebagai salah satu faktor penentu perbaikan produksi. Produktivitas dan produksi rendah tidak hanya berkaitan dengan masukan rendah, tetapi juga lahan kering dan kurang subur, air terbatas, lahan berpindah dan skala usaha sempit, dan gangguan hama penyakit serta terbatasnya penyuluhan pertanian. Hasil produksi rendah, sarana dan prasarana transportasi yang sulit dan mahal serta nilai tambah produk yang rendah serta akses pasar yang terbatas berakibat pada harga jual yang diterima petani rendah yang selanjutnya menciptakan pendapatan rendah.

Petani sepenuhnya tergantung dari harga yang ditentukan oleh pedagang pengumpul desa dan atau pedagang antar pulau. Produksi petani rendah dan kurang berkualitas karena pendampingan dan penyuluhan jarang dilakukan. Selain itu, masih pemilikan, lebih dari $52 \%$ petani memiliki lahan yang relatif luas (>1 ha) dan $48 \%$ memiliki lahan antara 0,5-1 ha. Namun ditinjau dari sisi pemanfaatan lahan, $83 \%$ petani hanya mengusahakan skala gurem yaitu $65 \%$ mengusahakan kurang dari 0,25 ha dan $18 \%$ mengusahakan antara 0,25 dan 0,5 ha. Hal ini disebabkan karena tenaga kerja terbatas, lokasi kebun berpindah-pindah dan tersebar, input rendah, dan skala usaha relatif sempit sehingga menghasilkan produksi rendah.

Petani di pulau-pulau kecil Kabupaten MTB menanam salah satu atau kombinasi antara ubi, kol kepala, kelapa, padi ladang dan jagung pada luas lahan rata-rata sekitar 0,25 ha. Hal ini merupakan strategi bertahan hidup untuk mengurangi risiko kegagalan panen (van Oostenbrugge et al., 2004) karena keterbatasan air serta ketidakpastian iklim agar terhindar dari kelaparan. Proses pemiskinan tampak makin menguat seperti yang terhadi di Pulau Jawa (Breman \& Wiradi, 2004) ketika kapital sosial makin lemah dan ketidakberdayaan petani menghadapi monopoli pasar pedagang antar pulau.

Tabel 3. Luas lahan, produksi dan produktivitas usahatani petani per musim per rumah tangga di delapan desa

\begin{tabular}{|c|c|c|c|c|c|c|c|c|c|c|}
\hline Komoditi & $\begin{array}{c}\text { Luas lahan } \\
\text { (ha) }\end{array}$ & & & & Prod & $\mathrm{i}(\mathrm{kg})$ & & & & $\begin{array}{c}\text { Estimasi produktivitas } \\
\left(\mathrm{kg} \mathrm{ha}^{-1}\right)\end{array}$ \\
\hline & & Amd & Aru & Ada & Kan & Ler & Mar & Mak & Lat & \\
\hline Ubi & 0,042 & 0 & 0 & 0 & 0 & 120 & 101 & 67 & 213 & 3.125 \\
\hline Kelapa & 0,408 & 0 & 0 & 485 & 0 & 0 & 0 & 0 & 0 & 1.182 \\
\hline Kac Tanah & 0,311 & 27 & 35 & 25 & 0 & 47 & 105 & 0 & 63 & 208 \\
\hline Kac Hijau & 0,289 & 73 & 135 & 55 & 150 & 36 & 28 & 0 & 0 & 233 \\
\hline Kol kepala & 0.258 & 0 & 0 & 0 & 0 & 0 & 0 & 480 & 355 & 1.606 \\
\hline Jagung & 0,255 & 0 & 0 & 0 & 0 & 0 & 0 & 232 & 0 & 928 \\
\hline Padi ladang & 0,160 & 95 & 275 & 0 & 0 & 0 & 0 & 0 & 0 & 1.156 \\
\hline
\end{tabular}

Keterangan: 0: tanaman tidak diusahakan atau habis dikonsumsi; Amd: Amdasa, Aru:Aruibab, Ada: Adaut, Kand: Kandar, Ler: Lermatang, Mar: Marantutul, Mak: Makatian, Lat: Latdalam.

terdapat perspektif lama bahwa teknologi yang baik untuk petani hanya datang dari satu sumber yakni Lembaga Penelitian padahal sumber teknologi dapat datang dari kearifan lokal masyarakat petani (Girsang et al., 2003). Ilmu pengetahuan dari Lembaga Penelitian dapat berperan mengentaskan kemiskinan melalui kerjasama lintas institusi, riset, temuan inovasi dan menciptakan desa binaan (Solahuddin, 2009). Namun lebih tepat jika teknologi berbasis kaji tindak pembelajaran partisipatif (Chamala et al., 1999; Girsang, 2009).

Petani miskin karena hanya mampu menguasai lahan sempit. Berdasarkan status

\section{Strategi Pengentasan Kemiskinan}

Selama ini strategi kebijakan kemiskinan didisain menurut cetak biru pemerintah pusat. Salah satu bentuk kelemahan intervensi kebijakan pemerintah adalah kurang melibatkan partisipasi kelembagaan lokal sejak awal proses mengidentifikasi masalah, kebutuhan, dan merencanakan kegiatan hingga pelaksanaan serta evaluasinya. Padahal pembangunan dan intervensi kebijakan akan lebih efisien dan efektif jika sejak awal melibatkan kelembagaan lokal.

Strategi penting dalam pengentasan kemiskinan di Indonesia cenderung bermasalah pada dua hal yaitu: tidak transparan dan bocor karena salah 
alokasi yang berkaitan dengan lemahnya kapasitas administrasi dan kualitas pendampingan (Perdana \& Maxwell, 2004). Belajar dari kelemahan tersebut, maka pengentasan kemiskinan di Maluku perlu dilakukan melalui pengembangan kawasan agribisnis komoditas unggulan inti di tiap pulau. Fokus dan lokus pembangunan sistem agribisnis komoditas unggulan inti dimulai dari kecamatan yang paling lemah dan miskin, yakni pengembangan rumput laut dan kacang tanah di Kecamatan Selaru, kacang hijau di Kecamatan Wertamrian dan industri minyak kelapa rakyat di Kecamatan Wermaktian.

Pada dasarnya penyebab kemiskinan di pedesaan bersifat multidimensi (Sumarto \& Widyanti, 2008) sehingga membutuhkan strategi penanggulangan yang terintegrasi. Strategi pengentasan kemiskinan demikian memerlukan pendekatan kebijakan ganda yakni konservatif dan neo-liberal (Alcock, 1997) melalui fasilitas bantuan modal, peralatan dan pelatihan dan pendampingan berkelanjutan serta kebijakan pasar yakni melindungi dan memproteksi dan mengelola produk unggulan petani secara terintegrasi sebelum memiliki daya saing di pasar yang lebih luas. Beberapa alternatif strategi penanggulangan kemiskinan 1) proteksi harga produk petani, 2) fokus pada komoditas unggulan lokal berdaya saing global 3) mengembangkan sistim pertanian adaptif dengan mengintegrasikan tanaman dan ternak, 4) mengembangkan kelembagaan dan organisasi petani dan 5) penyiapan sarana dasar di tiap kawasan pulau.

Inti dari pengentasan kemiskinan melalui agribisnis berbasis komunitas pulau kecil adalah fokus pengembangan komoditas unggulan yang dikelola secara terintegrasi-lintas sektor dan disertai prinsip keberpihakan pada yang miskin. Selama ini agribisnis dilihat sebagai suatu sistem dengan 5 subsistem yakni hulu, on-farm, agro-industri, pemasaran dan sub-sistem penunjang tetapi belum terjadi harmoni antar sub-sistem. Oleh karena itu, percepatan harmoni dan sinergi antar sub-sistem perlu digerakkan oleh lima aset modal penting yang saling terkait satu sama lain: modal sosial, modal manusia, modal sumberdaya alam, modal fisik dan modal finansial (Pretty \& Frank, 2000; Uphoff, 2000).

\section{Strategi pengentasan kemiskinan berbasis komunitas pulau kecil.}

Strategi pengentasan di pulau kecil penting dimulai dari perubahan paradigma berpikir dari perspektif kawasan sebagai alternatif terhadap perspektif sektoral. Kawasan pertanian perlu dibangun dengan perspektif agribisnis. Agribisnis komoditas unggulan yang hendak dibangun adalah satu produk satu kawasan, melalui pembangunan produk dari hulu ke hilir. Artinya, agribisnis dilihat sebagai satu kesatuan sistem dan disetiap sistem perlu dipercepat dengan pengembangan kelima aset modal secara proporsional. Dalam prakteknya, jika dimulai dari membangun kapital sosial dan kapital manusia akan lebih baik sebab kedua aset modal ini makin digunakan semakin tinggi nilainya sekaligus menjadi penggerak penting untuk mempercepat sinergi dan harmoni dengan aset modal lain. Integrasi pengentasan kemiskinan melalui agribisnis dan pengembangan aset modal untuk Kabutaten MTB disajikan pada Gambar 1.

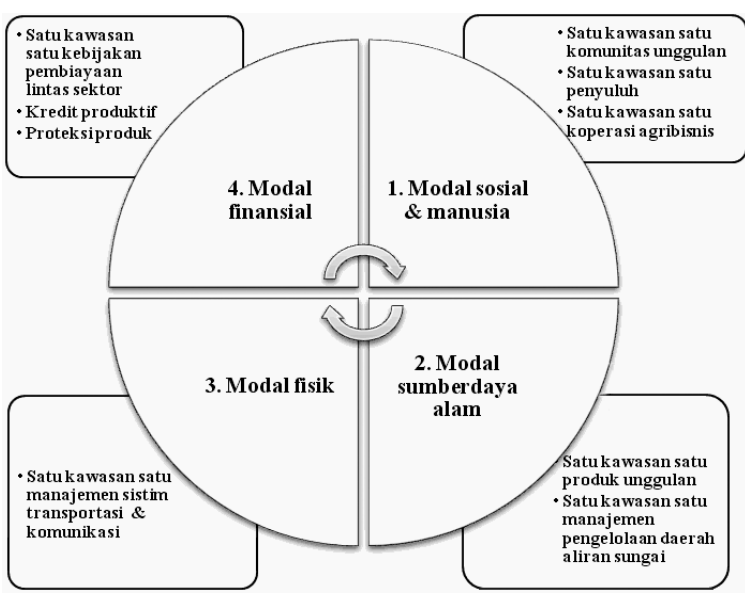

Gambar 1. Strategi agribisnis berbasis komunitas petani di Kepulauan Maluku.

\section{SIMPULAN DAN SARAN}

Kemiskinan di pulau-pulau kecil Maluku adalah kemiskinan pendapatan rumah tangga, bukan kemiskinanan ketiadaan pangan (kelaparan) maupun lahan usahatani. Berbagai faktor penyebab kemiskinan saling terkait dalam hubungan yang kompleks seperti akses input produksi terbatas, kesuburan lahan rendah sehingga terpaksa melakukan lahan berpindah, modal finansial hampir tidak ada, jumlah tenaga kerja produktif terbatas dan teknologi pertanian tidak berkembang. Lokasi lahan usahatani sempit dan tersebar dengan transportasi terbatas dan mahal. Akibatnya, produksi dan pendapatan petani cukup rendah dan hanya cukup untuk kebutuhan konsumsi keluarga (subsisten).

Strategi mengurangi kemiskinan harus terintegrasi dan komprehensif melalui pembangunan agribisnis komoditas unggulan inti berbasis komunitas di pedesaan pulau-pulau kecil. Metode ini 
dimulai dari pembangunan aset modal sosial dan manusia di kecamatan paling miskin yakni Tanimbar Utara di bagian Utara dan Selaru di bagian Selatan Kabupaten Maluku Tenggara Barat. Syarat keharusan strategi ini adalah komitmen dan aksi politik untuk menciptakan kerjasama lintas sektor (lintas dinas).

Implikasi selanjutnya adalah bahwa pendekatan satu arah kurang relevan dalam pengentasan kemiskinan tetapi lebih tepat berbasis kaji tindak pembelajaran partisipatif Dalam hal ini pengentasan kemiskinan dilakukan secara bertahap sesuai kondisi obyektif lapangan melalui pengembangan kawasan komoditas unggulan di tiap kecamatan dan atau pulau melalui kerjasama antara Science, Management dan Policy (SMP). Inti kompetensi swasta adalah ekonomi sedangkan pemerintah terfokus pada penyusunan regulasi. Kemitraan SMP ini penting guna mendekatkan petani dengan lembaga penelitian dan pemerintah untuk bersama-sama mengurangi kemiskinan di Indonesia, khususnya di kawasan pedesaan pulau-pulau kecil.

\section{DAFTAR PUSTAKA}

Alcock, P. 1997. Understanding Poverty. Macmillan Press. London.

Arifin, B. 2007. Diagnosis Ekonomi Politik Pangan dan Pertanian. PT Raja Grafindo Persada, Jakarta.

Bastiaensen, J, T De Herdt and B D'exelle. 2005. Poverty reduction as a local institutional process. World Development. 33: 979-993.

Chamala, S, J Coutts and C Pearson. 1999. Innovation Management: Participatory Action Management Methodologies for R,D,E \& Industry Stakeholders. Land and Water Resources, Research and Development Corporation. Canberra.

BKPMD Provinsi Maluku. 2007. Pembangunan Ekonomi Provinsi Maluku. Pemerintah Daerah Maluku-Badan Kerjasama Penanaman Modal Daerah. Ambon.

BPS Maluku. 2008. Maluku dalam Angka 2008. Biro Pusat Statistik dan Badan Perencanaan Pembangunan Daerah Provinsi Maluku. Ambon

BPS Maluku Tenggara Barat. 2008. Maluku Tenggara Barat dalam Angka. Badan Pusat Statistik Kabupaten Maluku Tenggara Barat dan Badan Perencanaan Pembangunan Kabupaten Maluku Tenggara Barat. Saumlaki.

Breman, J dan G Wiradi. 2004. Masa Cerah dan Masa Suram di Pedesaan Jawa: Studi Kasus
Dinamika Sosio-Ekonomi di Dua Desa Menjelang Akhir Abad ke-20. LP3ES dan KILTV, Jakarta.

Chambers, R. 1983. Rural Development: Putting the Last First. UK: Longman-Harlow.

Fakultas Pertanian Unpatti, 2007. Pengembangan Kawasan Pusat Pertumbuhan Agribisnis di Kecamatan Wertamrian dan Wermaktian, Kabupaten Maluku Tenggara Barat. Kerjasama Dinas Pertanian Kabupaten Maluku Tenggara Barat dan Fakultas Pertanian Universitas Pattimura. Ambon.

Girsang, W. 2009. Participatory Learning in Agricultural Extension: Constraints, Processes and Strategies Enhancing Adoption of Fasciolocis Control in West Java-Indonesia. Lamber Publishing Company. Koln.

Girsang, W, D Cameron and B Frank. 2003. Participatory learning processes enhance adoption of Fasciolosis Control Strategies in draught cattle in West Java, Indonesia. Pp. 273-284 in Environmental sustainability through multidisciplinary integration (MJ Mowlaei, A Rose and J Lamborn, Eds). The Cumberland, Marysville.

Harris-White, B. 2005. Destitution and poverty of its politics-with special reference to South Asia. World Development 33: 881-891.

Perdana, AA and J. Maxwell. 2004. Poverty Targeting in Indonesia: Programs, Problems and Lessons Learned. CSIS Working Paper Series (WPE) 083, March 2004.

http://www.csis.or.id/papers/wpe083 (Diakses 12/11/2009)

Pretty, JN and BR Frank. 2000. Participation and social capital formation in natural resource management: Achievements and lessons, paper presented to Changing LandscapesShaping Futures, Melbourne Convention Centre, Melbourne Australia, 2-5 March 2000.

Saragih, B. 2001. Paradigma Baru Pembangunan Ekonomi Berbasis Pertanian. Yayasan Mulia Persada Indonesia dan Pusat Studi Pembangunan Institut Pertanian Bogor. Bogor

Sayogyo. 1978. Lapisan yang paling lemah di pedesaan Jawa. Prisma 4: 50-62

Solahuddin, S. 2009. Pertanian: Harapan Masa Depan Bangsa. IPB Press. Bogor.

Stubenvoll, S. 2001. Traditional agroforestry and ecological, social and economic sustainability on Small Tropical islands: A Dynamic 
land-use systems and its potential for community-base development in Thioor and Rhun, Central Maluku, Indonesia. Unpublished $\mathrm{PhD}$ Dissertation. Berlin Technology University.

Sumarto, S and W Widyanti. 2008. Multidimensional Poverty in Indonesia: Trends, Interventions and Lesson Learned. The Smeru Research Institute. Paper Presented at the $1^{\text {st }}$ International Symposium on Asian Cooperation, Integration and Human Resources for Waseda University Global COE Program. Global Institute for Asia Regional Institute (GIARI), Tokyo, January 17-18, 2008.

Tambunan, T. 1995. Forces behind the growth of rural industries in developing countries. A survey of literature and a case study from Indonesia. Journal of Rural Studies. 11:203215.
Tjondronegoro, SMP, I Soejono and J Hardjono. 1996. Poverty in Indonesia, in Quilibria, M.G.(Editor), Rural Poverty in Developing Asia. Part 2: Indonesia, Republic of Korea, Philippines and Thailand. Asian Development Bank, Manila.

Uphoff, N. 2000. Understanding social capital: Learning from the analysis and experience of participation, in Social Capital: A multifaceted perspective (Partha $\mathrm{D}$ and $\mathrm{S}$ Ismail, eds), pp. 215-252. The World Bank. Washington.

van Oostenbrugge, JAE, WLT van Densen and MAM Machiels. 2004. How the uncertain outcomes assosiated with aquatic and land resource use affect livelihood strategies in coastal communities in the Central Moluccas, Indonesia. Agricultural Systems. 82: 57-91. 